\title{
Depoimento GUEDES
}

\section{Maria Cristina da Silva Leme}

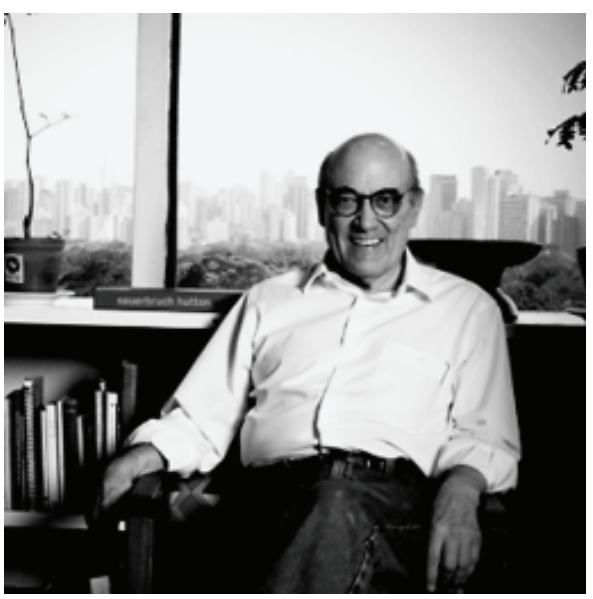

A entrevista com o arquiteto Joaquim Manuel Guedes Sobrinho foi realizada no dia 3 de abril de 2001, como parte da pesquisa que venho desenvolvendo sobre a formação do urbanismo em São Paulo.

Participaram da entrevista os arquitetos Paula Pollini e Rodrigo Guedes de Azevedo como bolsistas de iniciação científica. Paula realizou a pesquisa sobre a trajetória profissional que serviu de base para organizar a entrevista. Além de transcrevê-la e auxiliarme na edição, foi responsável pelo desenho das informações sobre o plano para Brasília.

Em São Paulo, a separação do ensino de arquitetura da engenharia foi resultado de um processo de autonomização, ocorrida no decorrer da década de 1940. Possibilitou a formação mais autônoma de um corpo de professores, recrutados entre aqueles que compunham os quadros do IAB, sintonizados com as idéias da arquitetura moderna.

O professor Luiz Ignácio de Anhaia Mello, nomeado primeiro diretor da Faculdade de Arquitetura e Urbanismo, apóia a formação do ensino de arquitetura mais vinculado ao movimento moderno, ao mesmo tempo em que concebe, junto do ensino de urbanismo, a organização do Centro de Estudos e Pesquisas de Urbanismo, o CPEU, para o desenvolvimento de planos urbanos.

Em outra vertente, o Movimento Economia e Humanismo, com a vinda do padre dominicano francês Louis Joseph Lebret ao Brasil, encontra um terreno fértil para a formação, em urbanismo, de jovens militantes católicos, em que se combinava um pensamento reformador, formulado a partir do conceito de solidariedade, e o desenvolvimento de uma metodologia de pesquisa empírica vinculada à ação ${ }^{1}$.

(1) Ver sobre a formação do movimento em São Paulo in: AMPARELLI, Celso. Joseph Louis Lebret e a pesquisa urbano regional no Brasil - Crônicas tardias ou história prematura, Espaço \& Debates, n. 37, 1994.

Com importante atuação tanto em urbanismo como em arquitetura, a entrevista realizada com Joaquim Guedes abriu a possibilidade de entender o novo perfil profissional, na passagem de uma formação do curso de engenheiro arquiteto da Escola Politécnica para o de arquiteto urbanista, nas primeiras turmas da nova Faculdade de Arquitetura e Urbanismo. O contato com o método de pesquisa do Movimento Economia e Humanismo insere Guedes nas questões da sociologia urbana e marca as propostas de projetos de novas cidades e planos urbanos.

As questões propostas, preparando a entrevista, abordaram temas, do primeiro período de formação na FAUUSP até o final dos anos 60. Havia a intenção, infelizmente não-realizada, de entrevistá-lo 
(2) Durante o período de 1976 a 1982, por encomenda do BNDES, desenvolve o projeto para a implantação da nova cidade de Caraíba. Distante cerca de $500 \mathrm{~km}$ de Salvador e 100 km de Jaguarari, sede do município, na caatinga baiana, em uma região de jazidas de cobre. A experiência foi analisada em sua tese de livre docência pela FAUUSP, Um projeto e seus caminhos.

(3) Oswaldo Arthur Bratke. sobre o período mais recente. Sua morte violenta e prematura, 27 de julho de 2008, pegou-nos de surpresa e não permitiu que esse projeto se realizasse. Nesta entrevista ele expõe suas idéias e fica evidente seu compromisso com a formação do arquiteto urbanista. Polêmico muitas vezes, ele procurava afirmar, de forma contundente, seu ponto de vista sobre o que considerava ser a arquitetura e o urbanismo. Discutimos e discordamos várias vezes. Nesta entrevista, seu ponto de vista parece-me exposto com clareza e paixão, marca de todas as suas ações, que espero ter resguardado da forma o mais fiel possível. É a homenagem de uma colega de oficio.

Joaquim Guedes: Deixe-me falar um pouco o que penso. Acredito que há uma gama muito grande de olhares sobre a cidade, os quais dão especializações, aprofundamentos, que têm a cidade como o centro, mas, no fundo, refletem preocupações, sensibilidades e possuem objetivo e capacidade operacional inteiramente distintos. Às vezes percebo-me discutindo muito isso, mais para demarcar campos e defender a necessidade de um aprofundamento de nosso campo, com cada vez menos gente. Por exemplo, em uma faculdade de arquitetura, considero hoje uma coisa, digamos assim, negativa, qualquer ênfase no conhecimento da numerologia das carências: falta esgoto, porque sempre falta, e esta exige um tão grande número de fatores, que não tem nada a ver com a arquitetura, e são preliminares, por exemplo: dinheiro, políticas, concepções de ação... muitas vezes envolvendo situações muito particulares, lutas locais que dão ênfase a uma coisa e não à outra... Isso vai da segurança, à falta de asfalto, à falta de escola, à densidade, ao congestionamento de tráfego... Tão amplo tudo isso, que qualquer ângulo que você pegue acaba estudando muito e sem necessidade. Aí, se a faculdade de arquitetura vai se preocupar com tudo isso, ela não faz nada. É isso que tenho sentido.

Você sabe que trabalhei muito com cidade e tive muitas oportunidades, às vezes, de pensar a cidade a partir do zero. O sítio era muito mais do que zero em Caraíba², por exemplo. O chão era tão horizontal, você não podia imaginar jamais de qual lado as águas corriam se chovesse, porque era uma mesa, caía para cá, vai para o lado contrário... Uma coisa terrível. Não tinha relevo, não era nada. Não só não tinha isso, como era uma coisa devastada, o calor, as rochas totalmente explodidas rolando em ambiente desolador. Recebi apenas os pontos em que havia as minas a serem exploradas, as minas de cobre, e uma relação de 1.181 empregos. A partir desses empregos e das características das atividades de cada emprego eu inferia, com alguma segurança, a origem dos empregados: Finlândia, Bahia, São Paulo, Chile, Canadá... e fui construindo a sociedade local de 20 mil pessoas. Tentando estabelecer algumas marcas de comportamento desses imigrantes no local, o impacto daquelas construções e como eles poderiam desenvolver atividades as quais demandassem espaço, relacionando uns com os outros.

Passei um ano pensando a cidadezinha. Esse trabalho foi da maior importância para eu pensar a cidade. Então, por um lado, não tenho coragem de dizer que isso não valia nada, mas, por outro, não recomendaria aos meus alunos que se metessem nessas coisas. Porque creio que você precisa trabalhar com o conhecimento coletivo o qual the dá uma série de insumos... e depois, o que pensei ter aprendido, no último momento fracassou.

Eu queria fazer uma cidade aberta. Conhecia a cidade da serra do Navio, que eu considerava um total fracasso, fracasso existencial e operacional. Por melhor que fosse o projeto de nosso amigo Bratke ${ }^{3}$, considerava a cidade errada. A cidade não é boa quando é feita de arquiteturas naquele padrão americano de cidade no campo. Ela é boa quando corresponde à população.

Mas acontece que a cidade a qual eu tinha feito a partir de uma leitura de sociedade, aspirando à democracia, à convivência e à pluralidade, na última hora, a direção da empresa, que tinha aprovado todo o meu projeto, passo a passo, por mais 


\section{OI2}

(4) Lourival Gomes Machado. de dois anos, decretou que não iria permitir a entrada de pessoas de fora, nãoempregados da companhia. Então, cercou a cidade e mandou colocar infra-estrutura em uma cidade chamada Abóboras, a cinco km dali. A empresa mandava, sob ação de polícia, todos os eventuais imigrantes de Caraíba, que viriam para ali naturalmente, para uma cidade com possibilidade de emprego, emprego secundário, como as empregadas domésticas e os ambulantes.

O que propus fracassou com a simples batida de martelo de um diretor, jovem de 28 anos. Todo o jogo de áreas que eu tinha preparado para esses imigrantes terem lugar, acabou em uma cidade sem gente, uma cidade vazia, de densidade muito mais baixa. Aquela vida que eu imaginava poder liberar com os arranjos os quais permitiriam a cidade ser aberta...

Penso que todos esses conhecimentos, sociais e políticos, são muito mais importantes enquanto ação objetiva, concreta, política. Em certo momento é mais importante que um tratado de sociologia sobre os movimentos de uma sociedade, em uma cidade, para a ação... Então fui cada vez mais deixando-me ir para o corner, um canto, um ponto de vista em que o interessante é ensinar e experimentar, preparar os alunos para fazerem formas ao homem, formas para atender às necessidades humanas, necessidades sociais e, nesse desafio, o arquiteto aguça, inclusive, sua capacidade de conhecimento do social, sua maneira e segundo as urgências de seu desenho, porque é uma forma preciosa de conhecimento que o sociólogo não vai ter.

Eu te contei que fiz o curso de Sociologia Política de tanto considerar importante por minha experiência com o Lebret. Quando me separei dele, fui fazer o curso na Escola de Sociologia e Política. Antes, fui conversar com o Lourival ${ }^{4}$, que tentou me desaconselhar: "Guedes isso não existe, sociologia urbana não existe, um dos únicos estudos que se conhece são sobre cidades médias americanas, fora isso não há nada, ninguém estuda metrópole, algumas estatísticas esparsas..." Então fui fazer sociologia geral e aprendi muito, era uma delícia o curso, economia social e política, economia urbana.

Mas, acredito que nossa maneira de tratar cidade tem de ser tentada com muita sensibilidade, muita paciência, muita abertura e deve estar ligada à urgência de inventar formas para a vida humana, isso te dirige, orienta, porque você vai ser obrigado a olhar a sociedade e ver o homem, tentar ler como eles usam o espaço. Isso é direto, não é a sociologia geral, não é a criminalidade... é uma coisa muito específica e isso ninguém ensina, só em uma escola de arquitetura, e que não faz, faz pouco, faz mal. Um dos problemas a resolver em nossas escolas, para dar uma oportunidade e verificar o que é a profissão do arquiteto hoje, deveria se concentrar no preparo do jovem para fazer formas e, aí, qualquer forma que você faça é um objeto urbano, obrigatoriamente. A exceção é a casa rural, Palladio, mas qualquer coisa que você faça é urbano, é gregário, e isso, para mim, é inevitável.

Não permito mais que os jornalistas me chamem de urbanista, porque quero ser arquiteto. Na Alemanha acabei de quebrar o pau. Sou arquiteto e tenho sobre nossa escola uma idéia, que você me ouviu falar no Rio. A expressão arquitetura e urbanismo e a faculdade nascida no Brasil é resultado da briga do Anhaia com o Prestes Maia. O Anhaia, naquela época, fazia um discurso do urbanismo social, urbanismo como uma coisa social, meio demagógica, inclusive, mas, na verdade, ele nunca tinha feito urbanismo, creio nunca ter aberto um plano para desenhar uma avenida, enquanto o outro fazia avenidas e o diabo. Por outro lado, os estudos sociais se ampliam muito no mundo, e mesmo nas escolas de arquitetura da Europa, chamados só de arquitetura, o grupo dos sociólogos está ganhando força. Lá, porém, o sociólogo não sai de seu chinelo, não enche o saco, não dá palpite e tem muita raiva de arquiteto, porque os arquitetos passeiam pela escola como príncipes, falam alto, falam grosso. Mas a verdade é que os estudos sociais têm tido um incremento muito grande. Então, eu diria que a realidade urbana, cada vez mais complexa, com cada vez mais estudos, atinge e mobiliza vários campos do saber, 
(5) Roberto Cerqueira Cezar. especializadíssimos, como legislação urbana. Nós precisávamos desenvolver nosso campo específico de conhecimento, de estudo, que teria como alvo sempre, como referência permanente, a invenção dos objetos urbanos, dos espaços habitáveis, e sempre, ao serem internos, são também externos e é por isso que não vejo nenhuma diferença ou limitação entre arquitetura e o resto, é tudo arquitetura para mim.

Maria Cristina: Nessa época, na FAU, existiam grandes e pequenas composições?

JG: Existiam, mas não eram relevantes, era sempre arquitetura.

MC: Você já começa a ter o urbanismo como cadeira?

JG: Era a cadeira do Anhaia, com ele fazendo discursos inflamados, ele era um demagogo infernal. Eram discursos de uma extrema capacidade de entusiasmar e sensibilizou-me demais. Fui formado a partir daquelas verdades, porém, em meu primeiro trabalho, Brasília, percebi que não dava pé, a cidade ter de ser limitada, ter o green belt, as zonas de sítios e chácaras, campos e verduras e isso era muito sistemático nele, eu fiz muitos projetinhos urbanos na base dessas regras de desenho. Mesmo assim, com todos esses erros de conceito, limitações de enfoques e esse primitivismo do pensamento do urbanismo paulista e brasileiro, foi altamente motivador. Saí da escola certo de ter uma missão em relação à cidade, que o negócio não era fazer arquitetura, a arquitetura seria produzida pela indústria de construção, pré-fabricados, e restava ao arquiteto pensar a cidade onde essas arquiteturas seriam expostas naturalmente e encontrariam seu lugar facilmente, de maneira harmônica, porque o urbanismo é harmonia e tal.

No quinto ano fui reprovado pelo Rino Levi e pelo Robertão ${ }^{5}$. Eles foram admitidos em maio e davam aula no segundo semestre. Eu me considerava formado, e era de uma auto-suficiência, de uma arrogância sem tamanho. O Rino dava aula solene, de professor italiano e o Roberto era o assistente. Então, o resultado: não fiz nenhum trabalho "imagine fazer esta droga de projeto de apartamentos, estou fora". Acreditava que ele não me reprovaria. Primeiro, porque era visível eu já ser uma pessoa formada, arquiteto e competentíssimo; segundo porque eu sabia mais do que ele, pois convivia com o Lebret e ele não sabia nada. Mas fui reprovado.

Procurei o Rino... que não me recebeu. O Robertão me recebeu e, muito simpático, explicou o problema: não podiam me dar uma nota sem um trabalho. Eles marcaram, para mim e mais quatro colegas reprovados, todos piores do que eu ainda, um dia, às 8 horas, para fazer um projeto. Chegamos às 8 e saímos de lá às 6 horas da tarde com um projeto e todos nós tiramos nove, dez, porque o projeto era formalmente fácil de fazer... E nessa ocasião tive a cara de pau de dizer: "- Professor, minha concepção é essa, o que acabei de declarar para você - o mundo não é mais para arquitetos, a arquitetura acabou, o negócio hoje é assim..." e contei para ele como eu via... Mas o interessante foi: de lá para cá, cada vez mais fui me convencendo do contrário.

Não existe plano, grande plano, plano geral, não existe planejamento de grande geometria. Você tem linhas gerais, certamente erradas e o dia-a-dia vai dizer, não é bem por aqui, é do outro lado. A briga, os conflitos e as conciliações são de uma grandeza extraordinária, muito maiores do que aquilo que a gente pode ter na própria cabeça. Pouco a pouco, fui me convencendo do contrário e acreditando muito nas ações das pessoas e em seus projetos. Não por acreditar no individualismo, no liberalismo, mas por crer que a vida humana leva cada um a cuidar, antes de mais nada, da própria respiração, da própria existência, da própria comida e, depois essa exigência fundamental, primária e individual, acaba levando à sobrevivência, obriga à agregação, à convivência, obriga às boas maneiras, ao bom comportamento ou até a criminalidade para se ter o que não tem. Foi essa a passagem do macro para micro.

Quando entrei, a escola começou com arquitetos modernos dando aulas, o Artigas, Abelardo de Souza, Ícaro de Castro Mello, Zenon Lotuffo. O próprio Anhaia tinha uma 
(6) Igreja Nossa Senhora do Brasil.

(7) Júlio Katinsky, professor do Departamento de História da FAUUSP. visão moderna e ele dava amparo a isso. Havia, também, um grupo de professores mais antigos, mais velhos - davam aula de história da arquitetura, como o Luís Simões Magro, que fez a Nossa Senhora do Brasill ${ }^{6}$. Ele dava uma aula formal e eu adorava, porque era uma das poucas aulas que te colocava em contato com a arquitetura mundial, com a cultura mundial. Os novos jovens arquitetos, também de uma pretensão sem tamanho, acreditavam que estavam ensinando para o mundo e era um saco o discurso, era de uma pobreza total. Assim foi a escola que eu conheci. Os livros eram poucos; logo depois da guerra, quais livros você tinha? Os americanos, saindo do esforço de guerra, a Europa devastada. As apostilas de matemática que a gente recebia, os livros eram apostilas escritas a mão por grandes matemáticos italianos e você recebia em papel jornal e comprava na livraria italiana. Eram tempos de muita precariedade, mas, ao mesmo tempo, uma grande ênfase na reconstrução do mundo que só poderia ser feita por arquitetos. Parti com ambições muito grandes e aprendi no erro, como estou dizendo, aprendi errando, eu fazia maus projetos; naquela angústia de tentar, errava mais ainda e houve momentos em que eu dizia: "Santo erro, porque se não fosse, como eu estaria perdido!"

MC: E o trabalho com Lebret?

JG: Eu conheci os Katinsky ${ }^{7}$ e fiquei muito amigo deles. A Liliana era muito amiga da Teresa, eram as únicas mulheres da escola; a Teresa no primeiro ano, a Liliana na segunda turma e eu na terceira, um ano mais atrasado que a Liliana. E começamos a ter muita convivência. A Teresa e o Julinho eram muito ligados aos dominicanos, eu não era, mas fui trabalhar com o Lebret. Não sei por que eles não foram, creio que não se interessaram. Fomos, o Domingos, a Clementina, a Liliana e eu. O Lebret foi fantástico. Eu desenhava, todos eram desenhistas também, mas éramos obrigados a ler o material para fazer a representação gráfica. Depois começamos a ler para corrigir o português e rever a datilografia e aí entendi o que o Lebret fazia. Mais tarde, comecei a trabalhar ativamente nas coisas dele. Separei-me no ano em que me formei. Trabalhei com ele enquanto era estudante na escola.

Foi o que ficou dessa convivência. Primeiro, uma fase curta mais religiosa que acabou em impasse católico de esquerda, porque o Lebret não dava um passo além do limite católico e isso levava, às vezes, a algumas incoerências. Em nenhum trabalho do Lebret você vai encontrar qualquer referência ao petróleo e, no Brasil, naquela época, era central, e também à reforma agrária, central. Todos os planos dele passavam longe disso. E para nós não podia ser dessa forma, tinha de ser analisado no conjunto; as políticas deveriam atender a essa necessidade de superação dos atrasos nacionais. Não que ele fosse vendido, mas ele era muito sabido, era também um grande comerciante e sabia, que, ao fazer um plano para o Lucas Nogueira Garcez, não podia falar nessas coisas. Ele se submetia acreditando que o ganho, até onde ele falasse, era sempre um ganho de grande significação.

Mas entendi o seguinte e foi uma luz em minha vida. O Lebret era especialista em análises de níveis de vida, inclusive o famoso "niveaux de vie de la population" e fazia análises no mundo inteiro pago pela ONU, ele era um especialista da ONU, e, com isso, ele desenvolveu alguns instrumentos de análise. Esses gráficos eram, basicamente, do seguinte tipo: não só uma sistemática de transformar em gráfico os fenômenos sociais - isso naquele tempo era uma ciência, uma coisa nova, era o começo da numerologia complexa das grandes máquinas de calcular velozes, ainda não da informática, não era computação. Ele começou a transformar números em gráficos, nos quais ele procurava expressar a realidade em quantidades e comparações.

Um dos gráficos mais impressionantes eram discos, com raios que passavam pelo centro, produziam setores opostos. Ele passava um traço nesses discos e embaixo colocava os fatores econômicos decodificados por ele em diversos tipos, padrões significativos, e, em cima, valores que chamo de sociológicos e éticos, a expressão não 
(8) Antonio Bezerra Baltar. é muito correta, estou traduzindo mal. Por exemplo, uma seqüência embaixo que seria: tem automóvel, tem rádio, como é que comem, tem fogão, a rua é asfaltada, tem escola e coisas assim... e, em cima, começavam: a cultura, valores associativos, níveis de formação, categoria de emprego, coisas assim... Era muito sofisticado, era de uma sofisticada precisão e de uma extrema simplicidade e eloqüência. Você via claramente. Ele examinava, por exemplo, cidades brasileiras, cidades européias, americanas e estabelecia padrões de medida compatíveis e você via - se não tem fogão também não tem universidade, se não tem não sei que diminui a proporção de isto com aquilo e aí vai... O tamanho das casas, o número de pessoas por quarto, uma série de coisas que revelavam padrões de vida. Muito cedo aprendi que havia uma correspondência direta entre o econômico e o social e depois, o que já era meu, entre o social e as formas de organização do espaço. Ele fazia na escala macro dos planos regionais e eu comecei a viver aquilo na minha arquitetura e no pensar a cidade. Acredito ter explicado quase tudo que você queria saber.

MC: O plano de Ourinhos.

JG: Foi com o Baltar ${ }^{8}$. Ele era o engenheiro que assinava, porque o Lebret precisava ter pelo CREA alguém para assinar os planos e o Baltar era o menino de ouro dele. Ele era catedrático no Recife. A ligação do Lebret com o Baltar não conheço em detalhes, mas os dominicanos tinham um grande número de padres, do Rio para cima, descendentes de famílias muito importantes do Nordeste, usineiros e tal, e esse pessoal era ligado ao Baltar. O Baltar também era um homem de esquerda, fundador do partido socialista, um pouco catolicão e tal, mas era de esquerda, não era do PDC. O partido socialista, tinha uma posição muito peculiar, pois conseguia não ser comunista, mas ser superinteressado no social, desde que ninguém comesse crianças, enquanto o PDC era uma confusão geral, de ir à missa e amar o próximo e o resto não é tão grave.

O Baltar era um primor de inteligência, um brilho pernambucano, tipo Gilberto Freyre, um cara cheio de verbos e tal. Muito ligado, muito falante, boa pinta, cheio de filhos, enfim, um primor de pessoa. Amicíssimo do Prestes Maia, com quem ele viajou para os Estados Unidos. Não sei se ele contava por ouvir dizer ou se ele teria estado mesmo nessa viagem com o Prestes Maia, seria uma coisa para vocês, historiadores, investigarem. Mas ele contava que o Prestes Maia, na viagem para os EUA, fazia assim: alguém pegava um texto e lia e ele repetia as palavras de trás para diante, a frase inteira, uma memória de elefante.

O Baltar convivia com os planejadores, que eram muito atrasados. Todos eles faziam um urbanismo de fora para dentro e não de dentro para fora, como eu imaginava que se devia fazer. No máximo, era aquela questão das avenidas, um pouco por mimetismo, um pouco por intuição de que um dia a gente precisaria de ruas largas e avenidas, como o Haussmann em Paris.

Havia muitas razões para fazer, sem serem muito racionais, com o perdão da explicação meio burra. O Baltar era um engenheiro que gostava de ler por ter uma cultura, como o Joaquim Cardoso, um engenheiro culto, que, de repente, aplicou-se nisso. Lembro ter achado muita graça, porque ele era especialista em fazer gráficos também, não era à toa a convivência com Lebret, então toda aquela parte ele fazia uma curva que expressava todas as relações de densidade daquele bairro, ou dos outros bairros, e com isso ele era um racionalista, matemático e tinha um amor pela sociedade, pelo humano e tentava, certamente, intuitivamente, trabalhar pelo social articulado à engenharia. Nunca diria que o Baltar foi um planejador urbano ou que fez planejamento urbano.

MC: Baltar, no plano para São Paulo, era o encarregado da parte urbanística.

JG: Ele sempre assinou os trabalhos, ele era o CREA, quem assinava tudo - índices urbanísticos, densidades. A questão das densidades era mais o Mário Laranjeira, 
também, engenheiro, independente do Baltar. Eu era muito amigo do Mário, ele vinha a minha casa, quando namorava a Zezé, e pediu-me para conseguir um emprego com o Lebret. Ele não queria trabalhar na construção civil porque se preocupava muito, na linha do católico, em trabalhar para o bem da sociedade. Tudo isso brincando muito, os anos me deram esse direito de brincar. Ele era muito sério.

Ele vai para Harvard para estudar urbanismo, planejamento, e volta para trabalhar com o Lebret. Acredito que ele falou comigo antes de ir e, como não havia o que fazer, não havia trabalho, era muito pequeno o trabalho, ele foi embora, até um pouco chateado. E escreveu-me várias vezes, várias cartas, contando como era, cartas longas, a gente tinha uma relação interessante. Tudo muito intenso, mas muito raro, nada íntimo, vamos dizer assim. Porque ele era um tipo muito sério, muito fechado, mas, mesmo ele sendo tão difícil e eu tão fácil, nossa relação era muito discreta, cerimoniosa e tal. Aí quando eu saí, ele entrou e fez São Paulo; pois saí um pouco antes de começar o Plano de São Paulo, entraram: Mastrobuono, Lamparelli ${ }^{9}$, Mário Laranjeira e uma porção de jovens, um pouco mais jovens do que eu.

MC: E Brasília?

JG: Olha, quando acabei Brasília e vi a natureza das pranchas que os outros colegas tinham feito, pranchas e maquetes, fiquei muito envergonhado, enfim, com muito receio de ter feito um trabalho ruim e tal. Porque os nossos desenhos, você viu

(9) Celso Lamparelli. alguma coisa, eram apenas uma colocação no papel de linhas, de diretrizes de áreas, e conceitos de utilização do solo à margem dessas linhas. Na verdade, era uma forma de ancoragem, de desenvolvimento urbano que a gente não queria definir, nós não quisemos fazer arquiteturas, não quisemos definir muito as coisas. É um trabalho ainda muito voltado à idéia de destinação do solo a certas atividades, mas não como na Carta de Atenas, isso porque nós queríamos saber a maneira de organizar a família, as comunidades, as frações sociais na cidade. Qual seria a forma com que essas famílias se aglutinariam, como viveriam pais e filhos e escolas, domingo, em dia de semana? E o que seria esta cidade? A partir daí, sabendo que ela se destinava a funcionários públicos e aos serviços de apoio, mas, os funcionários, como sendo dominantes e dominadores na cidade, porque seriam os reis e até hoje são, começamos a trabalhar isso, tentando trabalhar também com a variável - a mulher no trabalho, porque a gente sabia também que o funcionalismo público tinha a maior população trabalhadora feminina no Brasil, fora a agrária, que era desconhecida. Se isso era verdade, daí decorria alguma coisa em relação aos filhos: como organizá-los, como organizar os espaços para esse tipo de vida. Havia também essa ambição de os adultos precisarem ter uma vida adulta plena, política, social; portanto, que as crianças dessem folga; como dar folga? Imaginar que cada família teria uma empregada nordestina chegada aqui não era moderno, não era razoável. Como oferecer alguma condição? Então não fizemos isso, mas escrevemos tudo isso como uma oportunidade experimental, de investigação, já que era uma cidade que, antes de mais nada, tinha de ser uma experiência modelar.

Estudamos muito, nessa ocasião, os kibutz, naquela época muito pouco conhecidos. Rose Delprat, uma socióloga, cujo marido era um estatístico que trabalhava com o Lebret, Raimundo. Isso é uma coisa importante, também aprendi com esses caras, que um estatístico era um cara maravilhoso e fundamental, daí vem minha mania de trabalhar com números, porque me ajudam a pensar; encontrei outra maneira de usar números e isso dava prazer.

Rose Delprat vinha maravilhada com os kibutz. Apesar de ser uma pequena população em Israel, era a população, que, digamos assim, tinha fantasias nacionais. Os mais antigos, Ben Gurion, Golda Meyer, eram personalidades fantásticas, os grandes vultos de Israel saíam dos kibutz. Embora a massa comerciante deitasse e rolasse em Telavive, não tinha nada com os kibutz, os grandes políticos de Israel vinham dali, as grandes mentalidades e tal. 
Comecei a pensar nesse perfil de formação humana que o Brasil precisava. Por que não aproveitar o tipo de relação pai e filho, o tipo de relação inerente à estrutura dos kibutz e a seus propósitos? Então, comecei a acreditar nisso e recomendar, não porque eu fizesse no plano, a recomendar uma procura por parte do Estado, ao fazer Brasília, para toda a cidade ou para parte dela, uma investigação de relações familiares, de organização da vida cotidiana familiar totalmente diferente. Aprendi coisas fantásticas. No kibutz, as crianças tinham suas casas, seus dormitórios, seus refeitórios e os pais, como não tinham dinheiro, tinham, às vezes, um pequeno quarto. No começo, não tinham direito sequer a ter fogão no quarto, tinham um chaleira. Também comiam em restaurantes. Era uma vida muito econômica e, de fato, eles organizavam todos os recursos para dar prioridade às crianças, então as crianças tinham biblioteca, esportes, adultos que se dedicavam aos diversos jogos infantis, jogos de saber, jogos de divertir, jogos, de tudo. Porém, todos os dias os pais saíam do trabalho às 4 horas, íam para casa, onde sempre havia jardins, lugares de lazer e, também, espaços comuns sociais, salas. Nessas horas os pais ficavam com os filhos, das 4 às 7 horas. Segundo Rose Delprat, isso propiciava relações familiares extraordinárias e de uma consistência que a gente não conhecia em nosso capitalismo bárbaro, tupiniquim e predatório no qual as mães tinham três jornadas de trabalho, o pai nunca chegava em casa, acabava fugindo, porque estava envergonhado, enfim, aquela bagunça total. Lá, a falta de dinheiro e alguma organização prenunciavam uma nova sociedade.

A partir daí, comecei a imaginar: fazer as cidades seria pensar sobre arquitetura; você vê como eu destoava, sem querer, do modelo. Os edifícios não seriam formais, não haveria razão de fazer o edifício convencional porque não se vive, não se deveria viver convencionalmente, ou, pelo menos, deveria se investigar outras formas de vida. Daí a

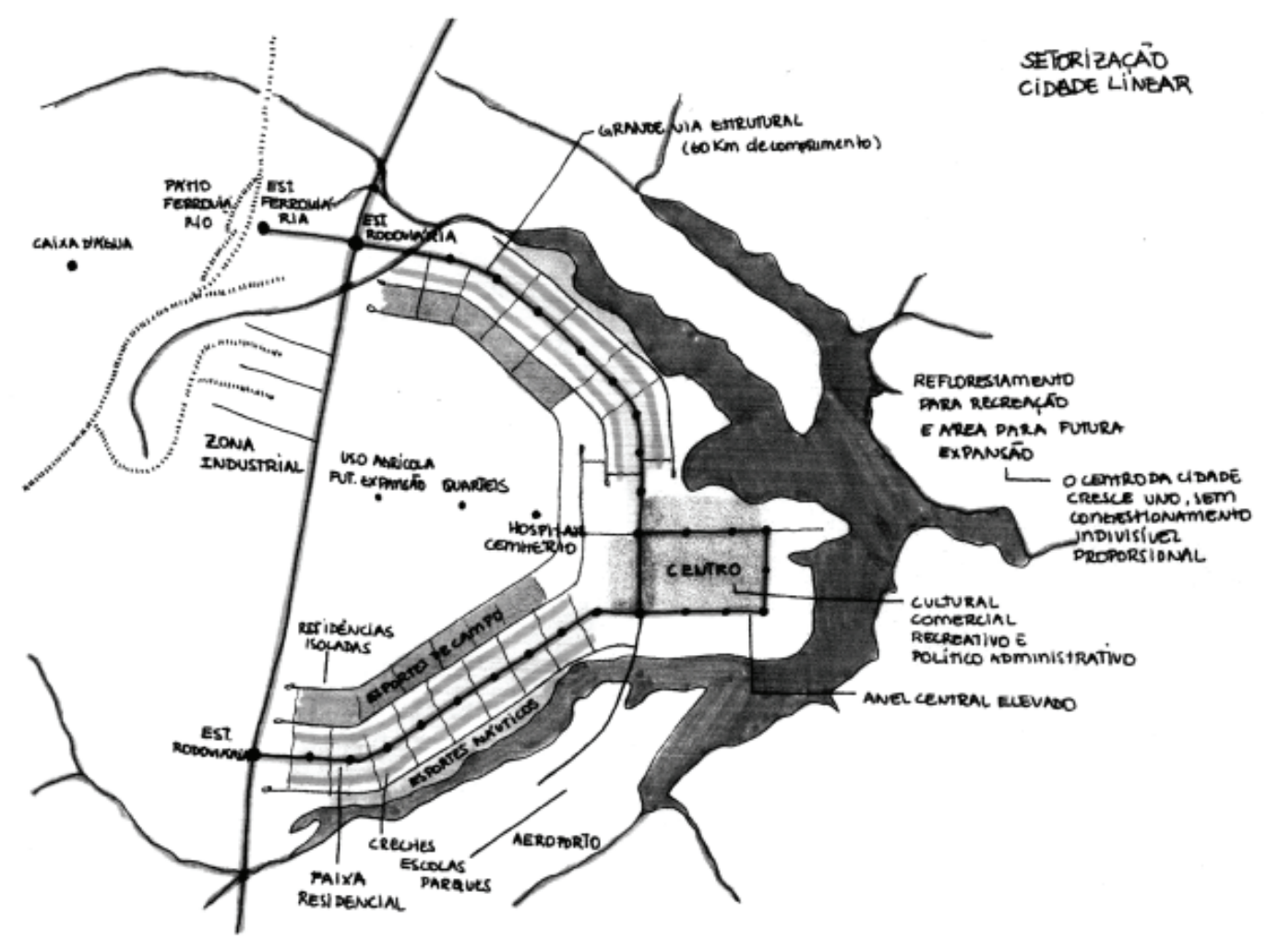

Esquema do Plano Piloto Elaboração: Paula Pollini 
(10) Domingos

Theodoro de Azevedo.

(11) Rino Levi. pensar em raios de ação por idade: a criança, até uma certa idade, moraria na base dos prédios, onde os pais tivessem suas unidades e elas teriam sua escolinha, seu dormitório também para que, embora separados, houvesse uma grande relação e o necessário controle familiar das coisas. Se eu começar a falar de memória, primeiro, vou errar muito, vou inventar muito, vai ser pouco produtivo...

Mas o que eu queria dizer é que nesse processo de pensar, de repente, eu me via a braços com uma formação urbana, muito maior do que jamais tinha ouvido falar. Também comecei a pensar que ninguém poderia imaginar o tamanho que iria ter, porque era um organismo vivo. Se, por acaso, tivessem energias e economias capazes de sustentar o desenvolvimento, ninguém seguraria e, se não tivessem, jamais chegaria aonde se tinha pensado.

Foi uma coisa interessantíssima: convidei algumas pessoas para trabalharem comigo, sociólogos, um padre, porque a igreja, naquele instante, era muito interessante - as organizações paroquiais, que, em francês, tinha um sentido muito especial de bairros.

Não me lembro de todos: estavam o Cândido Mendes de Almeida, que mencionei a você. Nessa altura, já estava longe em minha loucura. O Cândido vinha a São Paulo para fazer conferências e fui conversar com ele, fomos comer qualquer coisa fora. Depois, ele foi até a minha casa. O Cândido tinha 30 e poucos anos de idade, eu tinha 24, então havia aí seis a oito anos de diferença - não é grande coisa, hoje a gente sabe que é zero, mas a diferença entre nós era total, porque ele já era, a essa altura, membro do ISEB. Este era um lugar de iluminados que orientavam Getúlio Vargas, e depois o Juscelino. O Getúlio se matou e eles continuaram em cima, era como se ninguém os tirasse dali. Comecei a falar dessa organização e também sobre a importância da concentração para reduzir as distâncias, para facilitar a comunicação. Era preciso otimizar o sistema de transporte. Não existia metrô no Brasil e, em 1954, eu nunca tinha visto um metrô, ninguém viajava naquele tempo, nove anos depois da guerra. Mas eu tinha aquela brutal urgência de encontrar uma solução tecnológica. Eu dizia: é preciso tirar partido das virtudes da aglomeração, porque se ela é inevitável e indica um caminho de economia urbana, é preciso aproveitar as energias e as potencialidades da aglomeração, e toque aglomeração nisso - quanto mais aglomerado, mais eficiente.

Tive a felicidade de ter um amigo, o Domingos ${ }^{10}$. Ele é uma maravilha, porque ele leu tudo antes de você e quando ele fareja que você está com alguma preocupação, ele traz um livro para você. Então também cresci vagabundo, nunca pesquisei leitura, nunca fui pesquisador porque ele me punha no colo tudo o que precisava, na página certa, infernal! Ele destruiu o possível grande pesquisador que eu seria. Ele lia de leituras gregas a urbanismo contemporâneo, a sociologia do dia, e tal. Desde os que desenhavam as praças ao estudo do significado das praças e sua mecânica, tudo! Era um cara realmente muito interessante, hoje ele está aí, ele é mais velho do que eu um pouquinho, uns dois anos, e está na Sempla, é uma pessoa muito discreta, realmente... Devo muito a ele, e muito a Liliana, que era outra pessoa incrível, tinha uma formação cultural fantástica. Mas, voltando aqui ao Domingos e essa equipe, ele foi o primeiro a trazer-me o Ortega y Gasett, o primeiro que me pôs nas mãos o Eupalinos, e com a frase "il n' a pas de detail d'execution", como também meu primeiro Walt Whitmam, meu primeiro Fernando Pessoa. Sabe, eu podia descansar, não me preocupava com pesquisa bibliográfica. Acredito que na FAU deveria sempre se contar com um aluno como o Domingos para fazer a pesquisa para a classe.

Ele trabalhava com o Lebret, éramos colegas de escola. Ele era colega de classe de Liliana, que logo percebeu ser ele um fulano culto e, ele, reciprocamente. Aí, quando fui com o Lebret, convidei-o e fizemos um núcleo. Ele foi meu padrinho de casamento depois e éramos muito integrados; ele sempre foi um amigo muito leal, coisa rara na vida da gente. 
(12) Alison e Peter Smithson, arquitetos ingleses, integraram 0 Team $\mathrm{X}$.
O interessante é o seguinte: a cidade compacta, portanto vertical, embora no cerrado, distante de tudo, tinha uma densidade altíssima, mas também não havia limite. Não era como o Rino ${ }^{11}$, porque eu achava que não precisava, também não sabia o que eles quereriam fazer, qual economia faria isso lá no planalto sem tecnologia. Eu era muito pé na terra, jamais faria aquelas torres do Rino. Aquilo era uma fantasia irresponsável, quer dizer, não fiz aquilo para construir um desenvolvimento, fiz para investigar - quem quer pensar uma capital do Brasil não pode ter essa atitude. Em vez disso acreditava que iriam ser prédios de seis, oito ou dez andares, enfiando-se no Planalto, era um terreno ascendente, um platô, mas com uma ligeira declividade de $10 \%$, e, de repente, os andares iam acabando no solo, porque a declividade ia comendo as lajes. Os prédios, nisso, constituíram-se nossa única insistente sugestão; acreditava que o prédio deveria ser contínuo e você, de andar em andar, ia subindo e andando nesses andares como se fossem ruas. Minha preocupação era a seguinte: uma tal organização física exclui a rua convencional? Estamos diante de uma grande virada, o homem não andará apenas nas ruas, ele terá outras formas de locomoção mais confortáveis, mais agradáveis. Mas não cheguei a esboçar isso, sugeria que se investigasse algumas saídas as quais estavam sendo propostas por Alison ${ }^{12}$, ou então pelo próprio Corbusier, como as ruas internas. Alguma coisa teria de mudar.

Então, para nós, pensarmos isso já foi um tal desgaste e um tal cansaço, que a gente não queria entrar em arquitetura, além de eu estar convencido que ela surgiria de algum jeito. Esse foi o meu primeiro confronto com a contradição; lembra quando dizia que a indústria daria conta disso, não era preciso mais arquitetos e tal?

Mas a verdade é que se passou um mês e, na véspera de entregar o projeto, o Cândido me telefona. Ele estava em Ouro Preto, e diz: "Guedes, desde que falei com você não consigo mais sossegar, escrevi um texto e quero te entregar. Estou indo para São Paulo, vou passar por aí, chego à noite, você me pega no aeroporto..." Ou vinha de carro, não sei. Sei que fui e ele ficou em minha casa. Estava com um terno branco, era verão, a entrega foi em janeiro e fevereiro. Ele estava com camisa marrom, o terno de linho marrom, sujo completamente, de estrada, de pó, de tudo. Começou a falar e deu-me um rascunho do texto. 0 título era $A$ cidade vertical de Brasília ou o espaço acicatado do ocidental, nada mais nada menos - aí o que eu faço: "- Domingos, dá uma lida nisto aqui, pois com este título não sei o que a gente vai fazer." E o Domingos e a Liliana leram o texto. Horas depois: "Guedes, isso é maravilhoso, é exatamente o que você pensava, estávamos querendo, precisando." Aí fui ler e, de fato, era um texto muito interessante, texto histórico, eu diria, porque ele discutia a cidade vertical e sobra espaço - qual sentido tem isso? E no espaço acicatado ele procurava. Acicatado é como se um alicate pegasse; por exemplo, você pode dizer que é acicatada a cintura de uma formiga, que sai para cima e para baixo, o tórax e a bunda, enfim. Mas a verdade é que o texto era muito interessante. Coloquei-o como introdução, na frente.

Você sabe como se fazia isso, como todo o projeto era realizado em papel canson, folha de $1 \mathrm{~m}$ por 2,5 m, feito à mão, o Costinha desenhando, o Abrahão desenhando. Todo mundo. Enfim, várias pessoas, e ninguém dava um palpite; esses meninos tinham dois anos a menos que a gente, eles faziam aquilo com respeito religioso, como se fôssemos uns inspirados, eles não imaginavam o que fosse aquilo.

Aí fizemos essa cidade vertical, tinha uma alta densidade pontual, 1.000 habitantes por uma área próxima do terreno delimitado, mas esparsos no ambiente verde. Havia esportes de água próximos do lago, esportes de montanha para dentro e era uma linha só, começava com 500 mil habitantes na ponta, basicamente, e, se crescesse, continuaria até mais ou menos 1.200 milhão de habitantes. Esse número inventei na munheca, com minha mania numerológica. Como? Tomei a população federal que, supostamente, ia para Brasília, porque ninguém dizia quantos, mas com certeza vai mudar, e essa população federal de origem também exigiria, em cidade distante dos centros urbanizados, uma população de apoio própria, para ter um mínimo de 
autonomia, indústria primária, agricultura local. Nós produzimos todo o Distrito Federal em torno disso. Você vai encontrar, em nossos projetos, estradas rurais, centros de máquinas de agricultura, zonas e vales com proteção de árvores plantadas, árvores de espécies moles e outras duras, para fazer uma economia vegetal modelar, para fazer daquilo uma pequena experiência importante. Na parte central coloquei todas as atividades metropolitanas.

MC: Era um centro muito mais interessante do que um centro só administrativo?

JG: É, eu tinha. Nesse eixo, todos os ministérios, o Palácio Alvorada já estava por aqui, depois coloquei aqui do lado a administração do DF, esporte, aqui a Universidade, ali o grande comércio metropolitano e hotéis e atividades de banco e tal. E, para cá, a população com atividades mais ou menos locais, inclusive trabalho local. Esses pontos eram paradas de metrô de tal maneira, que em cada um deles haveria mais ou menos... sei lá quantos mil habitantes, o total era 1.200.000. Isso, segundo estimativas nossas, população capaz de tornar essa via econômica. Claro que esses ângulos eram abstratos, eu não sabia se o metrô faria essa curva ou não, e no centro ele era elevado, então a vegetação iria passar por baixo sem ser cortado por esse trânsito rápido e, aqui, ele era semi-enterrado.

Um grande eixo viário e, se não me engano, um grande eixo ferroviário em cima ligando os pontos que interessavam no platô lá no alto, havendo a possibilidade de um desenvolvimento especial residencial, se fosse necessário, uma coisa muito aberta.

Além disso, enfim, era muito emocionante; o mais interessante é que calculei: em 1990 a população deveria ser de mais ou menos 1.200 milhão de habitantes, porque eu dizia assim: se, hoje, perto de 60 milhões, tenho 500 mil, quando a população chegar a 200 milhões ou 150, não sei, vai ser duas vezes e meia isso. Então os números foram balizados dessa forma, e não era fechada. Não sendo fechada, eu não podia fazer bairros de funcionários, tinha de fazer estruturas que fossem assumidas pela população. Era uma estrutura capaz de crescer, como chamava, de tão organismo vivo que é a cidade; eu fazia comparações ingênuas, assim como: você não pode obrigar ou determinar o tamanho de uma criança, sua estatura, porque vai depender da alimentação, das condições de vida e da genética, e isso a gente nunca sabe o que é. Daí fiz uma coisa interessantíssima. Eu dizia: daqui a 30 anos, com novas tecnologias, a cidade poderá atravessar o lago de qualquer ponto, com muita eficiência e muita rapidez e quanto maior a velocidade e o conforto do transporte, mais longe você poderá ir, desde o centro para cá, e aqui você complementa o centro que vai estar ligado com aquele; portanto, é um centro só, e aqui você terá mais gente, e depois mais gente e com isso a cidade terá um desenvolvimento helicoidal. Isso é meramente teórico, mas era uma idéia muito interessante, muito gostosa de contar. Então, esse centro ia se desenvolvendo além do lago e a cidade também, seja compactamente, seja esparsamente. Mas minha preocupação é que, historicamente, toda cidade, todo centro urbano era rapidamente afogado pela periferia que o envolve, ou não se desenvolve, nada afoga nada, mas sempre que há um impulso para crescer, o centro é destruído pelo crescimento e aí há o que se sabe. Eu queria, assim, fazer um desenho que não condenasse o centro à sua autodestruição e nisso consistiu a experiência.

MC: Essa helicoidal parte do centro.

JG: Você transpõe o lago, portanto quanto mais você vai longe, maior é essa área central para cá. Você acaba tendo um centrão, o qual vai crescendo como a organização urbana que também cresceria, segundo fosse necessário. Se não fosse assim, seria de outro jeito, mas não seria jamais cidade-satélite aquilo que aconteceu. Você percebeu como essa conta era fácil. O interessante foi estimar a população da cidade, a partir da população do governo federal e estimar, sumariamente, os outros usos e os outros empregos via IBGE, pegando cidades equivalentes. Se ela começa 
com 500 mil hoje, no ano de 1990, dali a 30 anos, ela terá 1.200 milhão. Isso explodia e, quando coloquei esse estudo em meu relatório ocorreu aquela famosa briga do Oscar com o Paulo Antunes Ribeiro. O Oscar dizia ser aquilo um absurdo, pois queríamos uma cidade limitada, ela não pode ter metrô, isso é besteira, metrô é para cidade que não presta, sem solução. Brasília é uma outra coisa, é uma cidade humana.

O Milan ficou muito impressionado. Ele participou pouco do projeto, mas fez uma planta que sempre publico, pois foi a mais bem desenhada. Porém, em minha opinião, ela tem um defeito: é totalmente contrária do que eu imaginava estabelecer como diretrizes, mas, de qualquer maneira, é um gráfico. É a prancha que mostra só o centro com os prédios não-simétricos.

Procurei o Artigas, muito amigo meu, tínhamos uma bela relação, o Artigas já tinha sido preso, enfim, era uma situação política bastante brava naquele tempo, embora, com o Juscelino, fosse ainda um momento de certa liberdade. Ele me disse o seguinte: “- Guedes, eu não quero falar, não quero conversar, eu quero esquecer este assunto, eu estou muito chateado - ou qualquer coisa semelhante que me ficou na lembrança... eu acho que nós fizemos o melhor projeto, o projeto da Universidade de São Paulo." Lembro dessa expressão. Cristina! É perigoso falar comigo porque tem certas coisas que não esqueço: "o meu projeto é o projeto da USP" - fiquei chocado: porque seu projeto e não o meu? E ele não quis saber de conversar.

Começaram os artigos no jornal contra o Lúcio e o concurso. Um belo dia o Milan me mostra o projeto do Lúcio e diz: “- Guedes é incrível, eu acho que é muito parecido com o nosso." De qualquer maneira, ele tem também aquela rua horizontal com as curvas de nível, e o incrível é que poucos deles fizeram isso. Que eu saiba, só o Lúcio, e nós... que tem essa grande curva, o centro aqui naquela parte.

Uma das coisas importantes que o Domingos traz é o Ortega y Gasset. Ele era odiado pelos comunistas; para os barcelonenses e os comunistas da Catalunha, ele era um traidor. Comecei a ler e acreditava impossível esse tipo de posição. Porque ele não era antifranquista, depois ele se exilou em Portugal. Comecei a ler Ortega y Gasset. Andei procurando, porque nunca mais li esse livro. Era o Ensimismamiento y alteración. Meditación de la técnica, no qual ele mostra a relação do homem com a necessidade. O que é importante para o homem é o supérfluo, se bem que ele não vive também sem o ar e a comida. As necessidades objetivas são rigorosamente supérfluas - ele começa com esse jogo de palavras provocativo, e agrada muito, como você pode imaginar. Se bem que, de minha formação francesa, "jeux du mot, jeux du sot". Mas ele não é nada tolo. Voces falam francês? Jogo de palavras, jogo de bobo.

Ele afirma o seguinte: o que difere o homem dos outros animais não é a inteligência nem a capacidade de construir. Construir, muitos animais constroem e todos eles revelam algum grau de inteligência, o que distingue é a capacidade de planejar.

MC: Queria chegar até o seminário de reforma urbana.

JG: Para terminar essa fase. O homem é o ser que planeja, o planejar é inerente ao homem - acredito ter sido ele dos primeiros a usar essa palavra; o verbo inerir, que é latim, há quem diz não se usar mais, gosto de provocar, então eu uso. O ambiente humano é antinatural e artificial, é artificial e cultural. Com essa base comecei a pensar minha cidade, onde as árvores, a natureza entravam segundo outro esquema, o planejamento do Distrito Federal, do plantio de madeiras moles e duras, da exploração econômica dessas madeiras e não da natureza com um fetiche. Quando faço minha prancha chamada "Paisagem", chamei assim a prancha de uso do solo futuro. Creio ser a primeira vez em que a palavra paisagem é usada como sinônimo de uso do solo. Não era minha, vinha um pouco do Land draft alemão. Começou a ter esse significado para mim, e o paisagismo também começou a ser uma outra coisa. Acabei com dificuldade de continuar usando o mesmo vocabulário e 
pensando as mesmas coisas dominantes em meu ambiente de trabalho FAU e não tinha espaço para fazer outra coisa, para conversar, não tinha espaço na FAU.

Interessante é essa idéia da cidade, o papo de áreas verdes da ONU, não ter sentido. Quando saiu o livro da Janes Jacobs, seis anos depois, e encontro lá que a cidade é um ser vivo e esse negócio de área verde é besteira, cidade é cidade, campo é campo. A mim me agradava essa radicalidade, pois isso era condição de cidade compacta, de fácil comunicação - quanto mais árvore você põe, maior a distância entre as coisas; aí quem quer é a Shell. Não sei se você lembra - chegou um tempo em que a Shell começou a distribuir, na cidade de São Paulo, mudas de árvores para as pessoas plantarem; então você ia no posto e ganhava uma muda. Eu relacionava isso às cidades americanas, a cidades que já vi, e, no fundo, isso interessa à Shell, interessa ao petróleo, ao consumo do petróleo.

Enquanto minha cidade pretendia diminuir distâncias, reduzir o consumo de energia, e essa coisa toda. Assim essa maneira de pensar a cidade não passava pela Carta de Atenas. Mesmo assim caí duro quando, naquele dicionário que mencionei a você, no verbete do Lúcio, ele diz o seguinte: o mundo ficou perplexo quando, lá pela altura de 1956, alguém no mundo ainda fazia o plano de uma cidade com a Carta de Atenas, quer dizer, não tinha condição. Se você olhar o prestígio de Brasília, no mundo, é zero, como planta urbana, ninguém leva a sério.

MC: Mas o prestígio do Corbusier aqui era muito grande.

JG: Que aqui era, sim. De fato, o Lúcio e o Oscar fizeram estágio com ele - hoje observo isso de maneira muito curiosa porque vejo gente passar por meu escritório, ficam lá seis meses, um ano e depois vão embora. Foi isso que o Oscar e o Lúcio fizeram no escritório do Corbusier e vieram para cá implantar a novidade.

MC: Sobre o seminário de reforma urbana.

JG: Nunca falo sobre isso, nem sei se faz sentido, você vai fazer o favor depois de consultar para saber se permito que seja registrado ou não. Eu tinha assim essa atividade muito grande, sempre fui frágil e saudável, isso é terrível porque você não consome tanta energia porque não é tão grande, preserva energia e não pára. Sei que eu trabalhava muito, tinha feito Brasília, essa experiência de Brasília deu-me muito, entre aspas, muito destaque, porque, de repente, eu sabia uma coisa, tinha inventado uma coisa que ninguém sabia, nem o que era, mas, de qualquer maneira, tinha lá sua presença. E com a grande vantagem de ninguém ter visto o projeto, tinha sido perdido, se tivesse sido visto... talvez meu prestígio fosse menor. Brinco muito, inclusive comigo mesmo, felizmente.

Contiunuei no IAB e tinha entrado na discussão do social e, portanto, da cidade, feita de casas, de habitações. Eu escrevia também. Sempre escrevi muito mau, mas escrevia com grande dificuldade e, vira e mexe, estava metido em alguma comissão de redação qualquer. Fazia muitos manifestos, escrevia com o Saia e também sozinho. Escrevia com muita gente.

Quando, um belo dia, o Jango cria a Comissão Nacional de Habitação, o Montoro, como ministro do Trabalho, era o responsável, porque era a habitação para a classe operária, para a classe trabalhadora. Eu tinha uma participação política muito intensa naquele tempo, isso foi em 1960. Embora um grande setor de esquerda me considerasse um líder católico, o que eu não era, nunca participei de JUC, de nenhum movimento católico organizado, eu só tinha minha convivência com o Lebret, era ungido por ele. Quando foi trabalhar em Recife, fiquei aqui, com mulher e filho, não pude ir. Na primeira passagem ele veio para cá saber como era meu projeto para Brasília e passamos uma tarde inteira conversando (Depois quero voltar um pouco na questão dos cariocas e dos paulistas em Brasília).

Aí fiz parte dessa comissão. Estavam o Paulo Novaes, o sociólogo dos irmãos Roberto para o Plano de Brasília, o Mário Henrique Simonsen, o Hélio Modesto, um urbanista 
(13) Ícaro de Castro Mello.

(14) Almino Afonso.

(15) Miguel Arraes, governador de Pernambuco de 1962 , deposto pelo golpe militar de 1964. inglês no Rio, muito famoso e muito teórico, digamos assim, de quem eu gostava muito, eu, mais uma pessoa do Ministério e uma do Itamarati. Isso e uma entourage técnica para nos dar apoio. Asim comecei a trabalhar oficialmente em políticas de habitação.

Logo depois, o Icaro's me colocou em uma comissão da UIA. Eu dobrava o trabalho, aprendi muito, porque, ao trabalhar, confrontava-me com pessoas que trabalhavam. Fiz, assim, um aprendizado exponencial. Em três anos de trabalho, aprendi por dez.

No final do governo, Jango tirou o Montoro do Ministério, colocou o Almino ${ }^{14}$ e criou o Conselho Federal de Habitação para o qual fui, já sem o Montoro. Pensa-se em criar um Ministério da Habitação ou da Cidade e eu sou convidado para assumir esse ministério. Isso não chegou a ser criado, o Montoro preferia Ministério da Habitação e eu preferia o Ministério da Cidade. O Montoro queria ser ministro, e, como ele era politicamente mais forte, ele acabaria por ser ministro e, possivelmente, não seria nada. De qualquer maneira, para mim foi interessante o fim desse período de trabalho resultar em um convite desses. Eu estava em Santos passando um fim de semana com a minha família, em um apartamentinho na praia, e recebi um telefonema de manhã, de Brasíla: "Guedes, você aceitaria ser ministro"? Eu dizia: isso é trote. Naquele tempo isso era comum, porque o Almino tinha 32 anos, em 1962; eu tinha 30, o João Pinheiro 33. Depois todo mundo foi para a cadeia. Eu não fui.

Mas o interessante é que saí dali e o Almino saiu, dizendo que iria fazer reforma agrária. Eu não sabia bem qual o interesse da reforma agrária, mas, para mim, o país estava se urbanizando, então era reforma urbana. Um é urbano; outro, agrário, e tudo é reforma.

Eu estava muito inquieto com tudo que tinha acumulado nessa comissão - era diretor do IAB e membro do Conselho Nacional do IAB, e propus fazer-se um seminário para se recolher essa experiência, e sugeri dois diretores de São Paulo e dois do Rio. Como nesse mesmo tempo o Jorge Wilheim passou a ser representante do Brasil na Comissão de Urbanismo, propus, ele do Urbanismo e eu do Hábitat, fôssemos os dois representantes de São Paulo. Aliás, nem propus isso, mas acabou sendo. No Rio, o Hélio Modesto e o Maurício Nogueira Batista. Aí nos reunimos e fomos tocando uma coisa muito maior que a gente. Aconteceu de maneira absolutamente monumental. Foram 1.400 inscrições do Brasil inteiro. Conseguimos alugar o hotel Quitandinha e ficamos uma semana discutindo. Depois viemos para São Paulo e acabamos aqui. Foi interessante porque o presidente dessa comissão de redação era o Clóvis Garcia, um bom escritor, o Jorge também ajudou. Agora é tudo muito fantasioso, porque a gente não sabia bem quais seriam as balizas políticas, contávamos com algumas referências relativas à desapropriação, para fins habitacionais. Então eram arquitetos tentando diretrizes políticas para o país no sentido da cidade. Hoje não creio serem os arquitetos que fazem desse jeito, mas é a sociedade com seus recursos, suas conciliações, as suas exigências, brigas, que é partidária política, etc. Mas foi muito interessante e aprendi para burro, até o que eu não devia fazer.

Houve uma coisa interessante, nesse momento: uma reunião em minha casa, do Almino com o Arraes ${ }^{15}$, o Paulo de Tarso Santos, prefeito de Brasília e ministro da Educação, eu não sei, o Arraes, governador de Pernambuco, o Plínio de Arruda Sampaio, o dono do assunto de reforma agrária no Congresso Federal, o diretor do Le Monde e mais o adido cultural da França aqui em São Paulo - a filha dele se casou com um filho meu depois, e foi quem me levou à França dar aula. Aí esse sujeito organizou a reunião e começamos a falar com os brasileiros, sob véspera de golpe, ninguém sabia nada; então o Bernerri dizia assim: "Mas como é que vocês vão fazer a reforma em um país desse tamanho? E a tecnologia, e os recursos financeiros?" A resposta continha a seguinte tônica: "Primeiro fazemos a revolução, depois vamos ver como vai continuar", isso, naquela arrogância de jovens de 30 
anos, era uma maravilha: "primeiro vencer o inimigo, depois implantar a vida", mais ou menos assim.

A questão dos cariocas foi a seguinte: todo mundo estava querendo comer o Oscar, se possível sem assar e vivo, cru, e começaram a xingar também o mestre Lúcio e havia essa nossa simpatia pelo velho, embora ele fosse muito mais jovem do que sou hoje.

MC: Depois de ele já ter vencido o concurso?

JG: É, já com as primeiras publicações, Correio da Manhã, a carta do Paulo Antunes se desligando e mencionando nosso projeto e de mais um outro que não tinham querido ver... Porque foi ridículo. Como o Paulo Antunes não se dava com eles, ele era um arquiteto do Rio com formação francesa, e, portanto, pensava um urbanismo mais sofisticado, mais intelectual e tal, não chega nem a ser sociológico, mas intelectual. Aí o Paulo vai lá para a abertura da exposição, olha, apanha algumas coisas, os relatórios e vai embora. E o pessoal fica ali bebericando, whisky e tal.

No dia seguinte de manhã, conforme marcado, o Paulinho, você não chegou a conhecer. Ele era pequenininho, $1 \mathrm{~m}$ e 45 de altura, educadíssimo, uma maravilha de pessoa, eu gostava muito dele, e isso não seja uma visão diminutiva - era muito delicado e agradável como pessoa. A irmã era secretária dele, naqueles escritórios cariocas, eram ele, a irmã e dois velhos desenhando, possivelmente isso. Uma maravilhosa pessoa, com boa arquitetura pelo Brasil, ele era baiano.

Bom, o Paulo Antunes veio no dia seguinte, com as leituras concluídas e começa a querer discutir os projetos, e o pessoal diz: "Nós já escolhemos"; "Como, vocês não viram isto aqui?..."; "Não interessa..." E daí vem, nesse momento, a famosa frase: "Qualquer homem experiente vai para um concurso de beleza, coloca as misses em linha e já sabe qual é a mais bonita." O Paulo ficou chateado, ninguém quis discutir nada. Ele pediu demissão e foi embora. Aí ele quis falar de nosso projeto: "Isso aí tem mais de 500 mil habitantes, corta, desclassifica". E acabamos sendo desclassificados, tudo na base do whisky, segundo me passaram, e terminou assim a história.

Vimos aquele movimento todo e eu, de fato, fiquei chateado porque, conquanto o trabalho do Lúcio fosse aparentemente descuidado, era um trabalho feito com muita atenção e muita intensidade reflexiva, digamos assim, o que não nos parecia ter os desenhos dos outros. O que parecia ser meio ocasional, arbitrário, no do Lúcio não era arbitrário, ele estava tentando entender o que queria na cidade. O Milan, o Domingos e eu resolvemos ir para o Rio visitar o Lúcio. Fomos e levamos nosso projeto para conversar com ele, que nos recebeu por muitas horas, conversamos muito. Eu dizia: "Doutor Lúcio, o senhor fez uma geometria capaz de crescer, não ocorreu ao senhor que isso poderia dar outra dimensão ao seu projeto?" Eu não sei com que palavras eu disse isso, e ele me disse algo inesquecível: "Mas Guedes, veja Berna - tem 185 mil habitantes e é capital do mundo, uma grande capital não precisa ter muita gente, talvez seja até melhor não ter tanta gente assim." Isso nunca mais me abandonou porque eu acreditava não se tratar... para mim ela tem de ter o tamanho que quiser, e não conseguimos conversar muito. Em certa altura, o Lúcio era muito chorão, também sou um pouco, mas o Lúcio deixou rolar lágrimas na cara, dizendo: "Vocês mereciam ter ganho o prêmio, o concurso, e não eu". Essas coisas não têm o menor valor objetivo, ele estava emocionado com qualquer coisa, estava tomando muita porrada e fomos lá para cumprimentá-lo e prestar solidariedade, dizer que o projeto dele era o melhor, e gente estava contente por ter alguma semelhança com o dele porque isso também nos premiava. E assim foi muito solidário, agradável.

O Artigas ficou fulo, ele só veio a reconciliar-se com os comunistas do Rio muitos anos depois, já na ditadura, quando a união das forças era necessária, porque antes disso havia uma certa pretensão, penso eu, de hegemonia na esquerda comunista brasileira mais séria. 
(16) Afonso Eduardo Reidy.

(17) Miguel Badra Jr.

(18) Lauro Bastos Birkholz, professor titular da FAUUSP.

(19) Consultor em planejamento urbano no Plano Urbanístico Básico para a Prefeitura de São Paulo, 1968.
MC: Aí uma diferença entre São Paulo e Rio de Janeiro.

JG: Havia uma diferença curiosa, uma grande indiscrição, não tenho por que não ser indiscreto, pois essas coisas são importantes. Quando o Anhaia se aposentou, eu era muito ativo, como comentei com você, então quis discutir o que se vai fazer com a cadeira de urbanismo na FAU. Fui falar com o Artigas e conversamos muito sobre a FAU. Eu sempre fui muito tolo porque sempre falei muito aberto, pensava uma coisa e ia falar com quem acreditava dominar o assunto, mas não tive ressonância nenhuma. Ainda convidei o Artigas para irmos ao Rio trazer o Reidy ${ }^{16}$, o praticante de urbanismo no Rio, Morro de Santo Antônio, tem tudo a ver com tudo, o Flamengo, vamos trazer ele para cá. O Artigas teve a seguinte expressão: "Guedes, o Reidy e os cariocas são cultura do vermelhinho, filosofia de botequim, sai dessa, cara." - aí ele ficou entre o Badra ${ }^{17}$ e o Lauro ${ }^{18}$, e ficou o Lauro.

MC: Entre os projetos de cidades e os planos que você já fez, quais seriam os momentos mais importantes, os momentos de inflexão?

JG: Muito difícil porque cada trabalho foi um passo à frente. Sou muito grato ao céu, à luz do céu por ter feito Brasília. Quando, recentemente, reencontrei a Jane Jacobs, cujo livro eu deveria fazer o prefácio, precisei relê-lo. Na época não quis ler a Jane Jacobs. Assim que folheei, disse: “- Este negócio é romântico, eu não estou nessa..." e, realmente, é de um romantismo atroz, só mulher mesmo para chegar a esse ponto... Porque tudo que ela fala eu também queria ter falado e escrito. Alguma coisa eu escrevi, antes, se era a primeira publicação, eu publiquei também. Mas jamais teria aquela crença romântica na rua que ela tinha, de a rua ser anticrime, tudo aquilo torna o livro muito desatualizado até, mas foi muito importante para mim. Ela mudou o urbanismo, acabou com a Carta de Atenas.

Então isso foi muito importante, a minha ruptura com o Lebret, a utilização de todo o pensamento dele produzindo espaço. Está certo que eu não produzi coisa nenhuma, mas enfim, aproximando-me, observando caminhos de invenção de um tipo novo, livre e, ao mesmo tempo, rigoroso como reflexão. Depois vivi algumas experiências em planejamento urbano, dez anos depois, mas o grande momento foi o PUB $^{19}$. Fui convidado para fazer os modelos de uso do solo. Era a primeira vez que se ia trabalhar o uso do solo com modelos matemáticos, falei de meu interesse pelos números; então, inventamos, o Domingos e eu, uma metodologia de trabalho que decompunha a cidade em setores e subsetores, que conhecia as disponibilidades de áreas para os diversos usos, reconhecia a "vocação", palavra muito mal empregada, de certas áreas onde havia mais indústrias, e fomos alocando população centímetro por centímetro para viver e população para trabalhar, espaço de trabalho, industriais, de serviço, e acabamos tendo setores carregados com essas várias hipóteses de trabalho, mais concentração, menos concentração, aprendendo a trabalhar com hipóteses de desenvolvimento, mais ditadura; menos ditadura o que acontece? mais liberdade locacional, menos; o que seria uma coisa, o que seria outra.

Ao mesmo tempo, a Fundação Getúlio Vargas nos mandando recados: não se podia imaginar uma população com mais de 14 milhões de habitantes, porque o governo não queria isso, e quem financiava era o BID. Até queria saber como o Domingos veria isso tudo hoje. Eu queria 24 milhões, então ficou em 18. Havia um americano que nos mostrava que não poderia ser, por isso e por aquilo, então fizemos modelos intermediários. Esses estudos de modelo foram muito importantes. No modelo final existe uma coisa muito minha, não sei se é verdade, eu tenho como se fosse. É um plano que, apesar da rigidez gráfica, é extremamente aleatório. Você tem as concentrações de uso do solo não no gráfico da rede, mas nos pontos de chegada no chão, onde a vida se manifesta. Chegou aqui o sistema que andava lá por cima ou lá por baixo e vai ter a influência do uso do solo. Enquanto em minha experiência precedente pensava que o desenho da rua, aquilo que se risca no chão como rua, marca o uso do solo, em nosso plano não é, há uma intermediação entre 


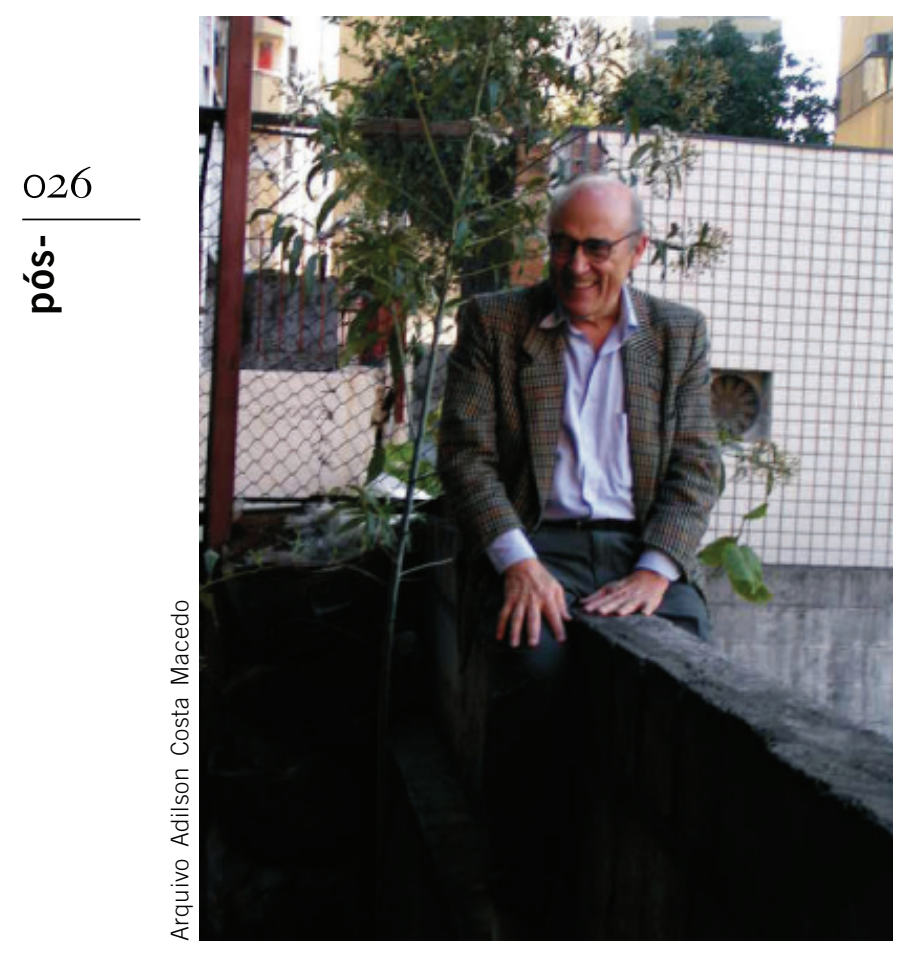

o uso e o gráfico. É mais abstrata a relação entre a circulação mecânica que pára de pontos em pontos e o acontecido embaixo. Então você vê um sistema ortogonal de alta eficiência, mas ele devolve à cidade a liberdade organizacional, inclusive a independência da utilização aleatória dos equipamentos sociais. Você chega em um ponto, como no metrô, por exemplo, ou por sistema viário expresso e, na chegada, você conta com várias alternativas de escolas, de comércio. Não fica aquela relação biunívoca entre comunidade e seu equipamento - o caso da unidade de vizinhança. Em Brasília rompi com as unidades de vizinhança.

MC: Essa é sua crítica às unidades de vizinhança.

JG: É, em Brasília rompi com aquilo, sem querer, quando me vi fazendo a minha cidade, era aleatória, tirando a criancinha da creche, a $300 \mathrm{~m}$ de seu apartamento, e o jovem do curso médio, do ginásio, já podia ir para qualquer ponto da cidade estudar, ir a centros de metrô e de lá procurar sua escola, e o adulto viria para o centro. Você teria a criança na base da cidade, o médio saindo de sua casa, seguindo os sistemas médios de transporte, depois iriam no metrô e estavam na rede e os adultos caíam no centro. Eu não falava em praça e espaço público, porque tudo é espaço público para mim, os locais de reunião, os locais de comer, os locais de esporte, a universidade, tinham a ver com toda a atividade central. Não era um gueto, então é esse o conceito de universidade no centro da cidade, no centro da metrópole. Quando digo que minha cidade não tinha nada, tinha vergonha do que tinha feito, mas, na verdade, havia uma fortíssima intenção organizacional, mas, ao mesmo tempo, acreditava que organização não era nosso direito - quer dizer, eu mal esboçava onde colocar as coisas para que elas pudessem se instalar com toda a liberdade, não sei se consigo dizer isso.

E no PUB também foi o que fiz. Participei desse plano, tentando não fazer um modelo de uso do solo fechado, mas um sistema viário que proporcionasse a máxima liberdade. Acreditava que a cidade grande tinha de ter um viário de máxima eficiência, não necessariamente o que os americanos faziam de plano viário, mas, sobretudo, porque transporte é uma condição de democracia, você não pode pensar em democracia se você não dá acessibilidade. Então, essas pequenas coisas que passaram a ser a minha religião.

\footnotetext{
Maria Cristina da Silva Leme cidades brasileiras.

Universidade de São Paulo

Rua do Lago, 876. Cidade Universitária

05508-900 - Sao Paulo, SP

(011) 3091-4548

crisleme@usp.br
}

Professora titular da Faculdade de Arquitetura e Urbanismo, Universidade de São Paulo, bolsista Produtividade $\mathrm{CNPq}$, coordenadora da área de Arquitetura e Urbanismo Fapesp, membro do Conselho do IPHS International Planning History Society e do Conselho Editorial da Revista Brasileira de Estudos Urbanos e Regionais, da Comissão Editorial da Revista Pós e coordenadora da rede interinstitucional de pesquisa sobre a formação do urbanismo no Brasil, a relação com os processos de urbanização e o impacto na estrutura urbana das 